\title{
The Effect of Halal Products and Brand Image on Purchasing Decisions with Purchase Interest as Mediating Variables
}

\author{
Wahyu Septianti, Ira Setyawati, and Dudi Permana
}

\section{ABSTRACT}

This study aims to know and clarify the influence of halal products and brand image on purchasing decisions with purchase intentions as mediating variables. Respondent - 98 employees (purposive sampling). Data collection is conducted through interviews and questionnaires. The data in the analysis uses path analysis (software SmartPls 3.0). The results of the study showed that:

(1) Halal Products have a significant positive effect on Purchase Intentions.

(2) Brand Image has a significant positive effect on Purchase Intention.

(3) Purchase Intention as a mediator in this study has a significant effect on the Purchase Decision.

(4) Halal products have a significant positive effect on Purchasing Decisions.

(5) Brand Image has a significant positive effect on Purchasing Decisions.

(6) Purchase Intention mediates Halal Products to Purchase Decisions and

(7) Purchase Intention do not mediate Brand Image against Purchasing Decisions.

Keywords: Brand Image, Halal Products, Purchase Decisions, Purchase Intention.
Submitted : March 08, 2021

Published : December 31, 2021

ISSN: $2507-1076$

DOI: $10.24018 /$ ejbmr.2021.6.6.807

Wahyu Septianti *

Mercu Buana University, Indonesia.

(e-mail: wahyuseptianti@ gmail.com)

Ira Setyawati

Binus University, Indonesia.

(e-mail: isetyawati@binus.edu)

Dudi Permana

Mercu Buana University, Indonesia.

(e-mail: dudi.permana@ ${ }^{@}$ ercubuana.ac.id)

*Corresponding Author

\section{INTRODUCTION}

Over the past two decades, Korean fever has almost spread throughout the world, with no exception in Indonesia KPOP (2020). Today's technological developments one of the main factors causing public enthusiasm for Korean Culture. This phenomenon is commonly referred to as Korean wave.

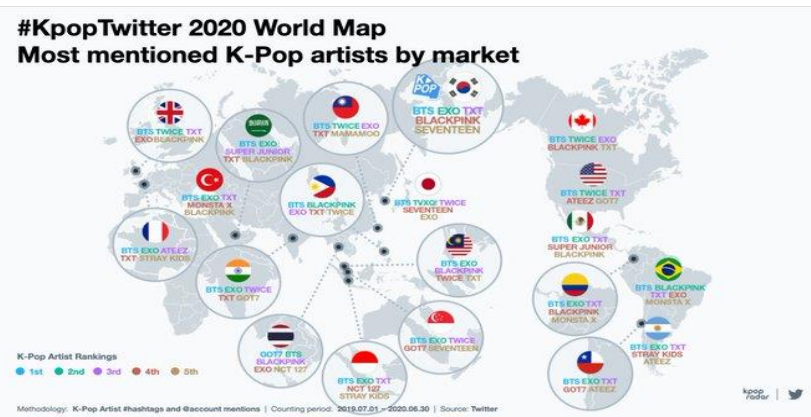

Fig. 1. KPOP 2020 Word MP Most Mentioned K-Pop Artists by Market.

The pervasiveness of K-Pop and K-Drama makes Korean culture also expand even implemented in daily life, including skincare, makeup, fashion, and food. Instant noodle products become the most popular since the viral Samyang Challenge or commonly known as Samyang instant noodles.

According to Puspita (2017), rumors about the halalness of a product will affect the product itself will make the purchase decision reduced, as happened to samyang noodles, which circulated calmly the content of lard in samyang noodle products became a serious issue in consumers in Indonesia. Due to this incident, there was a massive withdrawal by
BPOM by asking distributors to withdraw variants that were signaled to contain pig fragments. The existence of such rumors of course raises questions about the halalness of its products. It is certainly natural considering that Indonesia which has a population of more than 240 million people, and about $87 \%$ of the population is Muslims. Halal products become one of the important factors of purchasing decisions in consumers in Indonesia. According to the Ministry of Religion contained in kepmenag ri No. 518 (2001) on the inspection and determination of halal food: does not contain elements or illegal substances or prohibited to be consumed by Muslims and its management is not contrary to Islamic law

Because people's buying interest in Indonesia is influenced by the basis of measurable consideration based on the possibility of buying to own. According to Assael Henry. (2001) Purchase Intention itself is defined as the tendency of consumers to buy something or take actions related to buying and measured by the degree of possibility of consumers making purchases. Based on the results of a survey conducted by researchers to 40 people who have already purchased Samyang Instant Noodle products a total of 40 respondents.

According to the results of the survey indicates that in the process of making purchasing decisions made by consumers, consumers are very concerned about the information about the product listed on the product packaging. Brand Imagery can be Influence consumer buying interests. The factors that become the basis in the buying interest are met then fulfilled the requirements for a consumer to decide by searching for further information conducting an alternative evaluation. So that it reaches the stages of purchase decisions described into five stages in the purchasing decision-making process, 
namely problem recognition, information retrieval, alternative evaluation, purchasing decisions, post-purchase behavior, Philip Kotler (2012).

\section{LITERATURE AND CONCEPTUAL FRAMEWORK}

\section{A. Halal Products}

A product that circulates in Indonesia is guaranteed halalness, so it can be guaranteed a sense of security related to what is used and enter the body. According to Abu Muhammad al-Husayn ibn Mas'ud al Baghawi (1997) argues halal means something that is permissible by sharia because it is good. According to contemporary scholars, Yusuf alQaradhawi (1995) defines halal as something with which the buhul decomposes dangerously, and Allah allows it to be done. According to Yulianto (2019) there are three aspects of halal products to measure halal products namely:

\section{1) Security}

Individual processes (Muslim consumers) choose, organize, and interpret information about halal food products that have safety aspects, in terms of sources or raw materials, or processes.

\section{2) Religious values}

The process of individuals (Muslim consumers) choosing, arranging, and interpreting information about halal food products has aspects of religious values

\section{3) Health}

Individual processes (Muslim consumers) choose, organize, and interpret information about halal food products have health aspects.

\section{B. Brand Image}

According to Kotler (2012) the image is a consumer response to the overall offer given by the company or product and defined as a number of trusts, ideas and impressions of the community. Image to brand is related to attitudes in the form of beliefs and preferences towards a brand. To measure brand image in this study using three indicators as follows.

\section{Corporate Image}

The company's image includes popularity, credibility, as well as the company's network.

\section{Consumer Image}

Consumers are the user of a product or service. Consumer imagery shows a perception of someone using the product, the image of the consumer.

\section{E. Product Image}

Product image is the perception of a person directed towards a particular product. Product image is a group of associations that consumers perceive to goods or services.

\section{F. Purchase Intention}

Consumer buying interest is the stage where consumers form their choice among several brands that are incorporated in the device of choice, then ultimately make a purchase at an alternative that is most preferred or the process through which consumers buy an item or service based on various considerations. Yulianto (2019) to measure buying interest in this study using four indicators as follows:
1. Interested in finding information about products.

2. Consider buying.

3. Want to try.

4. Want to know the product.

5. Want to have a product.

\section{G. Purchase Decision}

Berkowitz in Tjiptono (2018) stated that the purchase decision is the stages through which the buyer passes in determining the choice of products and services to be purchased. To measure purchasing decisions in using three indicators as follows:

a. Make a purchase;

b. Product knowledge;

c. The need for products.

\section{H. Muslim Consumer Behavior}

According to Muslih (2017) stated that in Islam, a consumer's behavior must reflect his relationship with Allah SWT. Every movement of him, which takes the form of daily shopping is nothing but a manifestation of his dhikr in the name of God (2018). Thus, he prefers the way that Allah has restricted by not choosing haraam goods, not being niggardly, and not being greedy so that his life is safe in the Hereafter.

\section{Conceptual Framework}

Based on the background description of the problem and previous research, the research framework in the formulation of this problem can be seen in the following figure:

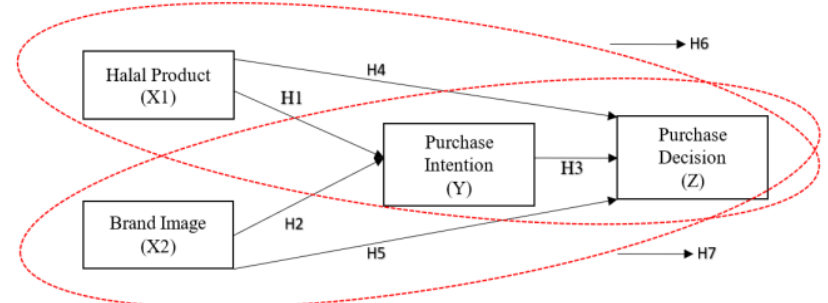

Fig. 2. Conceptual Framework

H1 : Halal Products Affect Purchase Intention In Food Imported From Korea

H2 : Brand Image Affects Purchase Intention In Food Imported From Korea.

H3 : Purchase Intention as a mediator in this study has a significant effect on the Purchase Decision

H4 : Halal products affect the Purchase Decision on imported food from Korea.

H5 : Brand Image Affects Purchase Decision In Food Imported From Korea.

H6 : Purchase Intention mediates halal products to Purchasing Decisions

H7 : Purchase Intention mediates Brand Image of Purchasing Decisions.

\section{RESEARCH METHOdOLOGY}

In the preparation of this study, the authors used quantitative methods with survey research. Then what is meant by the survey is a method used to get data from a 
certain.

This study used students domiciled in the Special Region of Yogyakarta (DIY) as the object of research, which selected students are those who have purchased processed food products imported from Korea, namely Samyang Instant Noodles.

Consumers with the last education Based on the results of research that consumers with the most last education or the majority are in the last level of high senior high school education with a percentage of $76 \%$, this is because Consumers Mie Instan Samyang has the ability to be well known among students who graduate in Senior high school and are continuing education is quite very welcome in the market.

To test and analyze the hypothesis made above, it is necessary to define variables that will be tested in this study into independent variables $(\mathrm{X})$ is Halal Products and Brand Image while dependent variables (Z) are Purchasing Decisions and variable moderating $(\mathrm{Y})$ is Purchase Intention.

\section{A. Population And Samples}

In this study the population used is using purposive sampling with criteria:

1. Students domiciled in The Special Region of Yogyakarta (DIY).

2. Students who have purchased processed food products imported from Korea namely Samyang Instant Noodles.

3. Make purchases through the online platform.

In determining the number of samples in this study is dengan refers to the opinion of Kline that the sample size that is 'tipical' for research using SEM PLS is 200 samples. In addition, Kline also cited Barrett's opinion that studies using the SEM PLS model using a sample size of less than 200 samples would be rejected, unless the sample count was strictly strict. The number of samples used in this study is 15 (indicator) $\mathrm{x} 6$ (parameters) $=98$ samples.

\section{B. Data Analysis Methods}

In this study, the authors used descriptive analysis. Used consists of Validity Test and reliability test that is assisted by Partial Least Square (PLS) method According to Sugiyono (2017).

The data obtained from the results of the next study were analyzed with a model of regression analysis of panel data using the help of Eviews version 10 program that aims to determine the influence of Halal Products (X1), Brand Image (X2), Purchase Intention (Y1), On Purchasing Decisions (Z1):

1. PLS (Partial Least Square).

Data analysis in this study using Partial Least Square (PLS) method.

2. Designing Measurement Model (Outer Model):

a) Convergent Validity;

b) Discriminant Validity;

c) Designing Structural Models (Inner Models);

d) Hypothesis Test (Bootstraping Resampling).

\section{RESUlTS AND DisCUSSION}

According to Sugiyono (2017) The results of the data analysis are presented descriptively from each variable obtained. Respondents in this study amounted to 98 factory consumers who were all tasked with going down directly in producing. Descriptive data presented include average or mean $(\mathrm{M})$, middle or median value (Me), mode (Mo), standard deviation (SD). Descriptive data also presents a frequency distribution table, and a histogram for each research variable.

Based on the results of the study, it can be seen that female consumers numbered 27 people with a rate of $28.42 \%$ while the male gender amounted to 68 people with a percentage rate of $71.58 \%$. Based on the data above there is no distinguishing or specific standards that companies apply to base on gender to determine what work is done, so all the same and the same scope of work does not have to be male and not necessarily female.

Consumers with the most last education or the majority is in the last level of high school education with a percentage of $76 \%$, this is because Kosumen Mie Instan Samyang has the ability to be well known among students who graduate from high school and are continuing education is quite very welcome in the market.

\section{A. Test Measurement Model (Outer Model) Reflective or Test Indicators}

1) Convergent Validity

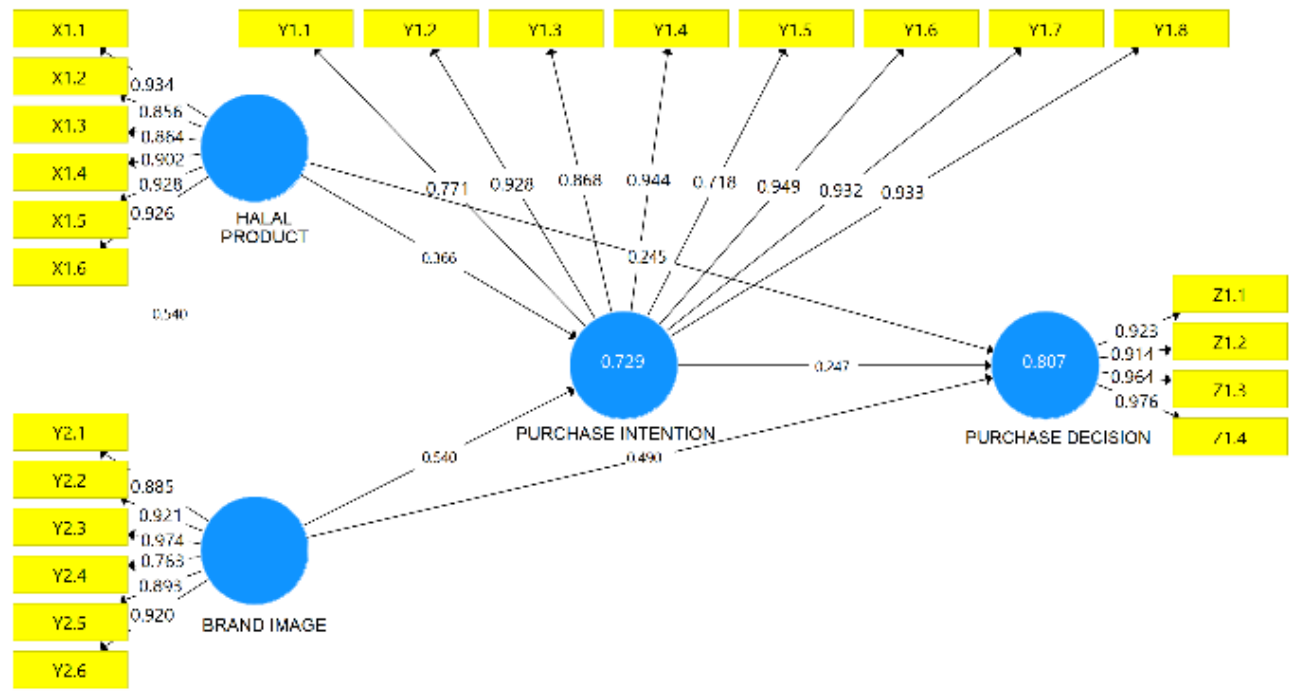

Fig. 3. Structural Equation Model. 
In the table below it is shown that the test of convergent validity in PLS with reflective indicators is significant because loading factors of all indicators on research variables is more than 0.7 according to Hengky, Latan, and Ghozali (2012).

TABLE I: VARIANCE EXTRACTED VALUE (AVE)

\begin{tabular}{ccc}
\hline No. & Variable & $\begin{array}{c}\text { Nilai Variance Extracted } \\
\text { (AVE) }(\text { AVE }>0.7)\end{array}$ \\
\hline 1 & Halal Products & 0.948 \\
2 & Brand Image & 0.955 \\
3 & Buy interests & 0.935 \\
4 & Purchasing Decision & 0.948 \\
\hline
\end{tabular}

Source: Results of data analysis using SmartPLS Version 3.2.9 (2021).

Table Results of data analysis using SmartPLS above shows that the variable AVE for all variables is greater than the rule of thumbs value of 0.5. 0.50.

\section{2) Discriminant Validity Testing / Discriminant Validity}

Validity of indicators on each research variable can also be done by testing the validity of discriminant/discriminant validity that is by checking the cross-loading value that is the correlation coefficient of the indicator to its construct compared to the correlation coefficient with other constructs Hengky, Latan and Ghozali (2012). The correlation coefficient value of the indicator should be greater against the construct than other constructs.

Based on the results of the discriminant validity test as seen in table above, shows that all indicators have a cross-loading value against the construct is greater than the value of cross loading against other constructs so that it is declared valid. It can be concluded that the construction of Halal Products, Brand Image, Purchase Intentions and Purchasing Decisions have a good discriminant validity.

\section{B. Evaluation of Structural Model (Inner Model)/ Hypothesis Test}

Based on Table V, it can be concluded that:

1) Halal products have an effect of 0.366 on Purchase Intention with T-Statistic value of 5,566 > 1960 and PValues of 0.000 .
2) Halal products have an effect of 9,090 on Purchase Intention with A-Statistic value of 4,314 and P-Values of 0.000 .

3) Brand image influenced 0.245 to Purchase Intention with T-Statistic value of 2,994 and P-Values of 0.003 .

4) Purchase Intention is influential at $0.490 \mathrm{t}$ for Purchase Decision with T-Statistic value of 5,898 and P-Values of 0.000 .

5) Purchase Intention influenced 2,247 on Performance with T-Statistic value of 2,588 and P-Values of 0.010 .

\section{1) Evaluating $R 2$ Value}

To evaluate the value of $\mathrm{R} 2$ based on the calculation results using calculate SmartPLS version 3.0 algorithm obtained the result of $\mathrm{R}$ value 2 which is 0.725 for the variable Purchase Intention and 0.833 for the variable Purchase Decision.

\section{2) Measuring Effect Size F2}

The result of calculating the effect size value (f square) with Smart PLS version 3.0 is in the table as follows:

1) Variable Halal Products to Purchase Intention has a value of $\mathrm{f}$ square which is 0.210 . This means that the variables of Halal Products have a strong influence on the structural level.

2) The Brand Image variable to Purchase Intention has a value of $\mathrm{f}$ square which is 0.457 . This means that brand image variables have a strong influence on the structural level.

3) Halal Product Variable to Purchase Decision has a value of $\mathrm{f}$ square which is 0.127 . This means that the variables of Halal Products have a strong influence on the structural level.

4) Variable Brand image to Purchase Decision has a value of $\mathrm{f}$ square which is 0.425 . This means that brand image variables have a strong influence on the structural level.

5) The Purchase Intention variable on a Purchase Decision has an $f$ square value of 0.100 . This means the Purchase Intention variable has a strong influence on the structural level.

\begin{tabular}{cccccc}
\multicolumn{5}{c}{ TABLE II: DisCRIMINANT VALIDITY TESTING } & \\
\hline \multirow{2}{*}{ Indicator } & $\begin{array}{c}\text { Halal } \\
\text { Products }\end{array}$ & $\begin{array}{c}\text { Brand } \\
\text { image }\end{array}$ & $\begin{array}{c}\text { Buy } \\
\text { interests }\end{array}$ & $\begin{array}{c}\text { Purchasing } \\
\text { Decision }\end{array}$ & Information \\
\hline X1.1 & 0.934 & 0.731 & 0.671 & 0.668 & VALID \\
X1.2 & 0.856 & 0.685 & 0.641 & 0.657 & VALID \\
X1.3 & 0.864 & 0.725 & 0.602 & 0.645 & VALID \\
X1.4 & 0.902 & 0.795 & 0.754 & 0.773 & VALID \\
X1.5 & 0.928 & 0.767 & 0.750 & 0.760 & VALID \\
X1.6 & 0.926 & 0.736 & 0.698 & 0.702 & VALID \\
X2.1 & 0.565 & 0.771 & 0.616 & 0.611 & VALID \\
X2.2 & 0.716 & 0.928 & 0.806 & 0.823 & VALID \\
X2.3 & 0.723 & 0.868 & 0.752 & 0.687 & VALID \\
X2.4 & 0.734 & 0.944 & 0.826 & 0.781 & VALID \\
X2.5 & 0.616 & 0.718 & 0.586 & 0.558 & VALID \\
X2.6 & 0.712 & 0.949 & 0.813 & 0.785 & VALID \\
Y1.1 & 0.625 & 0.743 & 0.932 & 0.719 & VALID \\
Y1.2 & 0.702 & 0.794 & 0.933 & 0.812 & VALID \\
Y1.3 & 0.748 & 0.780 & 0.880 & 0.811 & VALID \\
Y1.4 & 0.703 & 0.751 & 0.921 & 0.816 & VALID \\
Y1.5 & 0.786 & 0.824 & 0.924 & 0.840 & VALID \\
Y1.6 & 0.773 & 0.763 & 0.774 & 0.642 & VALID \\
Y1.7 & 0.724 & 0.798 & 0.893 & 0.841 & VALID \\
Y1.8 & 0.697 & 0.748 & 0.920 & 0.780 & VALID \\
Z1.1 & 0.746 & 0.829 & 0.762 & 0.923 & VALID \\
Z1.2 & 0.674 & 0.811 & 0.741 & 0.914 & VALID \\
Z1.3 & 0.746 & 0.858 & 0.809 & 0.964 & VALID \\
Z1.4 & 0.780 & 0.844 & 0.798 & 0.976 & VALID \\
\hline Source: Results of data analysis using SmartPLS Version $3.2 .9(2021)$. & \\
& & & & & \\
\end{tabular}


3) Predictive Relevance Testing (Q2)

TABLE III: PRedictive Relevance Test Results (Q2)

\begin{tabular}{cccc}
\hline Variable & SSO & SSE & $\begin{array}{c}\text { Q2(=1- } \\
\text { SSE/SS0) }\end{array}$ \\
\hline Halal Product & 392.000 & 150.972 & 0.615 \\
Brand Image & 294.000 & 86.825 & 0.705 \\
Purchase & 490.000 & 201.965 & 0.588 \\
Intention & & 95.000 & 0.677 \\
Purchase & 294.000 & & \\
Decision & &
\end{tabular}

Based on the Results of data analysis using SmartPLS about predictive relevance calculation (Q2) above, showing Q2 in this research model, endogenous latent variables have predictive relevance $(\mathrm{Q} 2)$ values greater than 0 (zero) so that exogenous latent variables as exogenous variables are able to predict endogenous variables i.e., Purchasing Decisions or in other words prove that this model is considered to have a good predictive relevance.

C. Results of The Influence of Independent Variables on Dependent Variables

1) Statistical Calculation Results with SmartPLS Program version 3.0.

Effect of Partially Independent Variables on Dependent Variables. The results of statistical calculations obtained are presented in the Table $\mathrm{V}$ for structural models with the following hypotheses:

Hypothesis 1 - Halal products have an effect of 0.366 on Purchase Intention with T-Statistic value of $5.566>1.960$ and P-Values of 0.000 .

Hypothesis 2 - Brand Image have an effect of 0.540 on Purchase Intentions with a T-Statistic value of $9.090>1.960$ and P-Values of 0.000 .

Hypothesis 3 - Brand image influenced 0.245 to Purchase Intention with T-Statistic value of $2.994>1.960$ and P-Values of 0.003 .

Hypothesis 4 -Purchase Intention is influential by 0.490 to purchase decisions with a T-Statistic value of $5.898>1.960$ and P-Values of 0.000 .

Hypothesis 5 - Purchase Intention affects 2,247 Performance with T-Statistic values of $2.588>1.960$ and $\mathrm{P}$ Values of 0.010 .

D. Hypothesis 6 - Purchase Intention Mediates Halal Products to Purchasing Decisions

Hypothesis testing with mediation effect was conducted with two steps according to Baron and Kenny:

a) Estimates the direct effect between independent variables and dependent variables. In this study, researchers conducted direct effect estimation that is the direct influence between halal product variables on purchasing decisions with explanations such as in Table V. Simultaneously estimating indirect effects by adding mediation variables between independent variables and dependent variables.

1. Hypothesis 7 - Purchase Intention mediates Brand Image to Purchase Decision

Hypothesis testing with mediation effect was conducted with two steps according to Baron and Kenny (1986) :

a) Estimates the direct effect between independent variables and dependent variables. In this study, researchers conducted direct effect estimation that is the direct influence between brand image variables on Purchasing Decisions with explanations as in Table V. Simultaneously estimating indirect effects by adding mediation variables between independent variables and dependent variables.

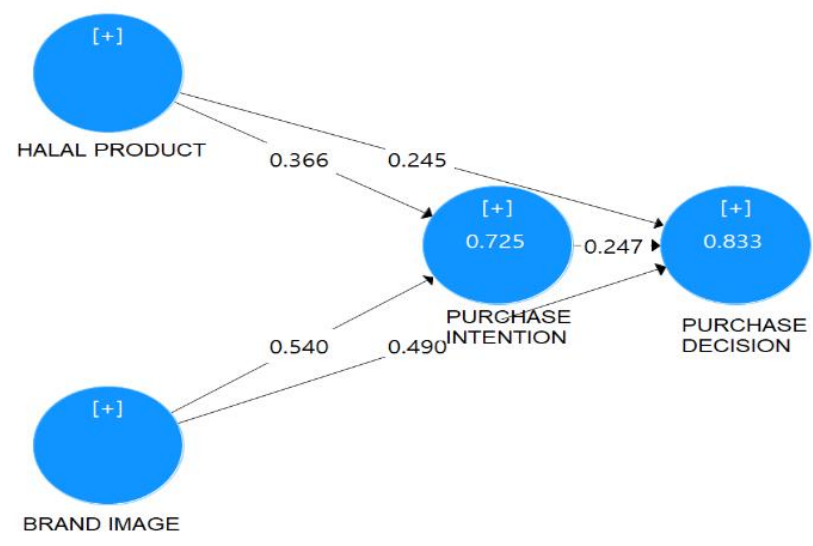

Fig. 4. Testing Model Indirect Effect with Smart PLS Program.

H6: Results of data analysis using SmartPLS on Table V, Coefficient value of halal product direct influence line on Purchasing Decision $0.245=0.060<$ the value of the coefficient of indirect influence of Halal Products facing the Purchase Decision is 0.090 and the value of $p$ value of the indirect influence of halal product variables on the Purchase Decision with "mediated" by the variable Buy Interest and the value of $\mathrm{p}$ value indirect influence of halal product variables on the Purchase Decision by mediated by the variable Interest Buy is 0.012 with A value of 2.357. Therefore, the value of $\mathrm{p}$-value obtained $<0.05$ and $\mathrm{T}$ statistics $>1.960$, it is concluded that the indirect influence of Halal Products on Purchasing Decisions is mediated by the variable Buy Interest.

TABLE V: EFFECT OF PARTIALLY INDEPENDENT VARIABLES ON DEPENDENT VARIABLES

\begin{tabular}{|c|c|c|c|c|c|c|}
\hline & $\begin{array}{c}\text { Original } \\
\text { Sample }(\mathrm{O})\end{array}$ & $\begin{array}{c}\text { Sampel } \\
\text { Mean (M) }\end{array}$ & $\begin{array}{c}\text { Deviation Standart } \\
\text { (STDEV) }\end{array}$ & $\begin{array}{l}\text { rt T Statistik } \\
\text { (O/STDEV) }\end{array}$ & T Table & P Values \\
\hline Halal Products (X1)-> Purchase Intention (Y) & 0.366 & 0.367 & 0.066 & 5.566 & 1.960 & 0.000 \\
\hline Brand Image (X1)-> Purchase Intention & 0.540 & 0.542 & 0.059 & 9.090 & 1.960 & 0.000 \\
\hline Halal Products (X1)-> Purchasing Decisions (Z) & 0.245 & 0.247 & 0.082 & 2.994 & 1.960 & 0.003 \\
\hline Brand Image (X2)-> Purchase Decision (Z) & 0.490 & 0.492 & 0.083 & 5.898 & 1.960 & 0.000 \\
\hline Purchase Intention (Y)-> Purchase Decision (Z) & 0.247 & 0.243 & 0.095 & 2.588 & 1.960 & 0.010 \\
\hline
\end{tabular}

Source: Results of data analysis using SmartPLS Version 3.2.9 (2021).

\begin{tabular}{|c|c|c|c|c|c|c|}
\hline & $\begin{array}{l}\text { Sample } \\
\text { Asli }(\mathrm{O})\end{array}$ & $\begin{array}{l}\text { Sample Mean } \\
\text { (M) }\end{array}$ & $\begin{array}{l}\text { Standard Deviasi } \\
\text { (STDEV) }\end{array}$ & $\begin{array}{l}\text { T Statistic } \\
(\mathrm{O} / \mathrm{STDEV})\end{array}$ & T-Table & P-Values \\
\hline $\begin{array}{l}\text { Halal Products (X1) -> Purchase Intention } \\
\text { (Y)-> Purchase Decision (Z) }\end{array}$ & 0.090 & 0.090 & 0.0380 & 2.357 & 1.960 & 0.012 \\
\hline $\begin{array}{l}\text { Brand Image (X2)-> Purchase Intention (Y)- } \\
\quad>\text { Purchase Decision }(\mathrm{Z}))\end{array}$ & 0.133 & 0.130 & 0.053 & 2.512 & 1.960 & 0.019 \\
\hline
\end{tabular}

Source: Results of data analysis using SmartPLS Version 3.2.9 (2021). 
H7: Results of data analysis using SmartPLS on Table V. The coefficient value of the brand image's direct influence on the Purchase Decision $0.4902=0.240>$ the coefficient value of the brand image's indirect influence on the Purchase Decision is 0.133 and the value of the $p$-value of the indirect influence of the brand image variable on the Purchase Decision by mediating by the Buy Interest variable is 0.019 with a $\mathrm{T}$ value of 3.006 . Therefore, the value of $\mathrm{p}$-value obtained $<0.05$ and $\mathrm{T}$ statistics $>1.960$ it is concluded that the indirect influence of brand image on the Purchase Decision is "not mediated" by the variable Purchase Intention.

\section{DISCUSSION}

\section{A. Effect of Halal Products on Purchase Intentions} (Hypothesis 1)

The value of $\mathrm{p}$-value of the variable influence of Halal Products on Purchase Intention (Halal Products, Purchase Intentions) is significant with a $\mathrm{p}$ value of 0.000 , T statistic of 5.566 and the original sample marked positive. Because the value of $p$ value obtained is significant, $T$ statistics $>1.960$ and original samples marked positive then Ho rejected and concluded that Halal Products have a positive and significant effect on Purchase Intention, the maximum Halal Products are fulfilled then the higher the level of Purchase Intention and vice versa.

\section{B. The Effect of Brand Image on Purchase Intentions (Hypothesis 2)}

The value of $\mathrm{p}$-value variable influence of Brand image on Purchase Intention (Brand image of Buy Interest) is significant with p-value of $0.000, \mathrm{~T}$ statistic is 9.090 and original sample is positively marked. Therefore, the value of p-value obtained is significant, T statistics $>1.960$ and the original sample marked positive then $\mathrm{H} 0$ rejected and concluded that Brand image has a positive and significant effect on the Interest to Buy, the better the brand image of a product then the higher the consumer's Purchase Intention, and vice versa.

\section{Effect of Halal Products on Purchasing Decisions (Hypothesis 3)}

Based on the value of $p$-value the variable influence of Halal Products on Purchasing Decisions (Halal Products Purchase Decisions) is significant with a p-value of $0.003 \mathrm{~T}$ statistically of 2.994 and the original sample marked positive. Because the value of $\mathrm{p}$-value obtained is significant, $\mathrm{T}$ statistics $>1.960$ and original samples marked positive then Ho rejected and concluded that Halal Products have a positive and significant effect on the Purchase Decision, the more appropriate it is to be held a product with Halal lebel then the higher the purchase decision made by consumers and vice versa

\section{The Effect of Brand Image on Purchasing Decisions (Hypothesis 4)}

The value of $\mathrm{p}$-value variable influence of brand image on purchase decision is significant with p-value of $0.000, \mathrm{~T}$ statistically of 5,898 and original sample marked positive. Because the value of $\mathrm{p}$-value obtained is significant, $\mathrm{T}$ statistics > 1.960 and original samples marked positive then Ho rejected and concluded that brand image has a positive and significant effect on the Purchase Decision, the greater the brand image that a product gives to consumers than the higher the Purchase Decision, and vice versa.

\section{E. Effect of Purchase Intention on Purchasing Decisions (Hypothesis 5)}

The value of $p$-value variable influence of Purchase Intention on Purchase Decision (Purchase Interest Purchase Decision) is significant with p-value of 0.010 , T statistically of 2.588 , and original sample marked positive. Because the value of p-value obtained is significant, T statistics $>1.960$ and the original sample marked positive then Ho rejected and concluded that The Purchase Intention has a positive and significant effect on the Purchase Decision, the higher the purchase decision, and vice versa.

\section{F. Purchase Intention mediates Halal Products to Purchasing Decisions (Hypothesis 6)}

The coefficient value of the direct influence of Halal Products on the Purchase Decision 2.2452 $=0.060<$ the coefficient value of the indirect influence of Halal Products on the Purchase Decision is 0.090 then the Halal Product to the Purchase Decision is mediated by the Purchase Intention variable.

\section{G. Purchase Intention Does Not Mediate Brand Image to Purchase Decision (Hypothesis 7)}

The coefficient value of the brand image's direct influence on the Purchase Decision 0.4902=0.240> the coefficient value of the brand image's indirect influence on the Purchase Decision is 0.168 then the Brand Image to the Purchase Decision is not mediated by the Purchase Intention variable. Based on the theoretical studies above, it can be indicated that The Purchase Intention does not mediate the Need for Appreciation of The Purchase Decision.

\section{CONCLUSIONS AND SUGGESTIONS}

\section{A. Conclusion}

After based on the results of research and discussion can be put forward some conclusions as follows:

1 Halal products have a significant positive effect on Purchase Intentions.

2 Brand Image has a significant positive effect on Purchase Intentions.

3 Halal products have a significant positive effect on purchasing decisions.

4 Brand Image has a positive effect on Purchasing Decisions.

5 Purchase Intention as a mediator in this study had effect on purchasing decisions.

6 Purchase Intention mediates Halal Products to Purchasing Decisions.

7 Purchase Intention does not mediate Brand Imagery against Purchase Decisions.

\section{B. Suggestion}

In this study, the authors also advised interested parties to this research, among others:

1) For Marketers of Samyang Instant Noodle Products: 
A. Related to the supplier of Halal Products Samyang Instant Noodles, should be in developing product innovations to be considered again the requirements of fulfillment of halal lebel it is certified Halal from MUI, so that the brand cira of samyang Instant Noodle products is positive. The better the image or the greater consumer awareness of the brand (awareness) will encourage consumers to buy instant noodle products samyang.

B. With regard to suppliers, should improvements be made especially on consumer Purchase Intention factors, there are many consumers who have an interest to buy based on the factor Want to Know and curious (interested in trying). Related to the lack of information about Mie Insten Samyang, should organize a food event about imported food products from Korea that are halal in Indonesia and include elements of samyang instant noodles in it so that consumers know and like imported food products from Korea, especially its Samyang Noodles

2) For further research :

To see the interest in buying and purchasing decisions more broadly, researchers interested in conducting similar research is expected to observe and explore more about the problems contained in halal food products and other objects in general by adding other variables, in addition, it is also advisable to try to use intervening variables other than Purchase Intentions such as Marketing Strategy, Marketing Mix, Quality of Service or Consumer Behavior.

\section{REFERENCES}

AG.Suyono, Sukmawati, S., \& Pramono. (2012). Pertimbangan Dalam Membeli Produk Barang Maupun Jasa. Intidayu Press, 11(13).

Al-Bagawiy, Abu Muhammad al-Husain bin Mas'ud al-Farra, Ma'alim atTanzil, jil Tahqiq Muhammad Abdullah an-Namr, Utsman Jam'ah Dhamiriyah. Cet.IV, Dar Thibah li an-Nasyr wa at-Tawzi', 1417 H./1997.

Alfian, I. (2017). Analisis Pengaruh Label Halal, Brand dan Harga Terhadap Keputusan Pembelian di Kota Medan. At-Tawassuth, 2(127).

Al-Qaradawi, Y. (1995). Musykilah al-Faqr wa Kaifa 'Alajaha al-Islam, translation by Syafril Halim, Kiat Islam Mengentaskan Kemiskinan, Jakarta: Gema Insani Press.

Andi Tjiptono, F., \& Chandra, G. (2012). Pemasaran Strategik. Andi.

Budiman, \& Riyanto, A. (2014). Kapita Selekta Kuesioner Pengetahuan dan Sikap dalam Penelitian Kesehatan. Jakarta: Salemba Medika, 57-66.

Hengky Latan, \& Ghozali, I. (2012). Partial Least Square: Konsep, Teknik dan Aplikasi SmartPLS 2.0 M3. Badan Penerbit Universitas Diponegoro. (pp. 368-389).

Keputusan Menteri Agama RI Nomor 518 Tahun 2001 (2021), Tentang Pedoman dan TataCara Pemeriksaan Dan Penetapan Pangan Halal, Assael Henry. (2001). Consumer Behavior. Edisi keenam. New York: Thomson Learning. 57-66.

Kline, R. B. (2011). Principles and Practice of Structural Equation Modeling (Third Edit). The Guilford Press.

KPOP [@KPOP]. (2020). Word MP Most Mentioned K-Pop Artists by Market.2020:

Source:https://twitter.com/TwitterData/status/1308194746167369735 $? \mathrm{~s}=20$.

Madhavi et al., (1996), Food Antioxidants, Marcel Dekker Inc, New York, 41-70.

Muslih. (2017). Analisis Pembiayaan Mudharabah Terhadap Peningkatan Laba Bersih Pada PT. Bank Perkreditan Rakyat Syariah Amanah Insan Cita William Iskandar Medan. Jurnal Ilmiah Manajemen \& Bisnis, 18(1), 73-88.

Puspita. (2017). Penjualan Samyang Halal Merosot 30 Persen: https://megapolitan.kompas.com/read/2017/07/10/15364531/penjuala n.samyang.halal.merosot.30.persen pada 19 mei 2018.

Philip Kotler, G. A. (2012). Principles of Marketing. New Jersey: Prentice Hall. 89-90.
Republika. (13 March 2015). Mana logo halal yang resmi. https://republika.co.id/berita/koran/dialog-jumat/15/03/13/nl524k9mana-logo-halal-yang-resmi.

Sangadji, E.M., \& Sopiah. (2013). Prilaku Konsumen: Pendekatan Praktis Disertai:Himpunan Jurnal Penelitian. Andi, 57-60.

Sugiyono. (2017). Metode Penelitian Kuantitatif, Kualitatif, dan R\&D. Alfabeta.

Yulianto, E. (2019). MINAT BELI (Survei Online Pada Pengikut Akun Instagram @ safiindonesia). Jurnal Administrasi Bisnis (JAB), 77(1), 20. 